\title{
Earthworms: 'Soil and Ecosystem Engineers' - a Review
}

\author{
Roshan Babu Ojha ${ }^{1, *}$, Deepa Devkota ${ }^{2}$ \\ ${ }^{1}$ Adjunct. Assistant Professor, Department of soil Science Purwanchal University HICAST, Kalanki, Kathmandu, Nepal \\ ${ }^{2}$ Technical Officer (soil Science) Agronomy Division, Nepal Agriculture Research Council Khunaltar, Lalitpur, Nepal \\ *Corresponding author: roshanbachhan@gmail.com
}

Received October 17, 2014; Revised October 17, 2014; Accepted November 04, 2014

\begin{abstract}
Earthworms can alter the soil environment by changing soil properties. They have great potentiality to enhance soil physical properties like bulk density, infiltrability, hydraulic conductivity, porosity, aggregate stability. Due to this ability they are only species which plays significant role in pedoturbation. Similarly, their role in nutrient cycling and organic matter breakdown is of unique interest. Earthworm cast fortified with the microbial population. Increasing microbial activity in soil, increases the nutrient mineralization and release. Earthworm activity enhances root distribution so that immobile macro nutrients like phosphorous and other micronutrients, which are absorbed by plant through root interception, are easily available to the plants. Hence, earthworms play important role in bioturbation, they are considered as 'soil engineer.' However, their activity differs with the agroecosystems. Their population density is more in reduced tillage system than conventional tillage system, aerobic condition than anaerobic conditions, grasslands than forest. Low population of earthworm was found in dry land agroecosystems. But earthworm presence in extreme environment is not studied well yet. So, this paper was reviewed to explore the role of earthworm as soil and ecosystem engineer. This was already established fact but main aim of this paper is to collect the related information and conclude the future research prospects to strengthen the earthworm role as soil and ecosystem engineer.
\end{abstract}

Keywords: earthworm, bioturbation, pedogenesis, nutrient cycling, soil and ecosystem engineer

Cite This Article: Roshan Babu Ojha, and Deepa Devkota, "Earthworms: 'Soil and Ecosystem Engineers' - a Review.” World Journal of Agricultural Research, vol. 2, no. 6 (2014): 257-260. doi: 10.12691/wjar-2-6-1.

\section{Introduction}

Earthworms are the docile creatures of soil ecology. Earthworms are also called the 'ecosystem engineers' (Lavelle et al., 1997; Hale et al., 2005) as they have great potentiality to change soils and plant communities. Earthworms are macro fauna commonly found in the tilled soils, grasslands and other agro ecosystem. About 800 genera and 8000 species of earthworm are recorded in the world (Edward, 2004) which belongs to the order Oligochaeta. Many authors agree on the beneficial role of earthworm in the soil but few reviewers and researchers point to the negative effects (Agarwal et al., 1958; Rose and wood, 1980) of introduced earthworm in the soil fertility and crop production. Barios et al. (1987) reported the positive effects of earthworms in nutrient mineralization and release of nutrients in the soil system.

Three major types of earthworms found in the soil ecosystem; which are classified as a) Epigeic, b) Endogeic and c) Anecic (Bouche, 1972). Epigeic species feeds on the upper surface while endogeic made the permanent deep burrows. Anecic species resides near subsurface soil region. They have their own morphology and have own feeding system. Epigeic species mostly feed on plant debris. So, they are mostly responsible for breaking down complex organic residues and mineralize nutrients. However, endogeic species mostly feed soil and built permanent burrows. There is more microbial activity around the burrows.

Earthworm density is lower in the dry land agroecosystems (Johnson-Mynard, 2007). On comparing with the reduced tillage and conventional tillage; earthworm population density was found more in the reduced tillage system (Edward and lofty, 1982; Wardle, 1995; Emmerling, 2001).In reduced tillage system lower manipulation of soil creates less soil disturbance (Chan, 2001), less physical injury of earthworm (Lee, 1985) and more food supply \& congenial soil conditions (Kladivko, 2001). Hence, there is more presence of earthworm in no till system.

In aerobic ecosystem, earthworms perform well but under anaerobic ecosystem (paddy field) their activity is limiting (Zorn et. al., 2008; Schutz et. al., 2008) that consequently effect their role as ecosystem engineer. However, certain researches focus on the importance of earthworm, either introduced or native, in increasing rice productivity (Chutinan et. al., 2010). Gates (1972) reported that, only one earthworm species Drawida beddardi remains active in flooded condition. So, there is necessity of more research to verify earthworm as soil and ecosystem engineer at various agro-ecosystem.

\subsection{Earthworm and Drilosphere Concept}

Drilosphere is that part of soil which is influenced by the earthworm activity. It a fraction of soil that contains 
earthworm burrows and casts which is highly populated with microbial load. In Figure 1, for the formation of the biogenic structures, major roles were played by the Ecosystem engineers i.e. earthworm in association with microflora. For the digestion of complex organic molecules earthworms occupies the major fraction. It shoes that, earthworm activity within the drilosphere enhances microbial activity (microflora) along with the other biological components.

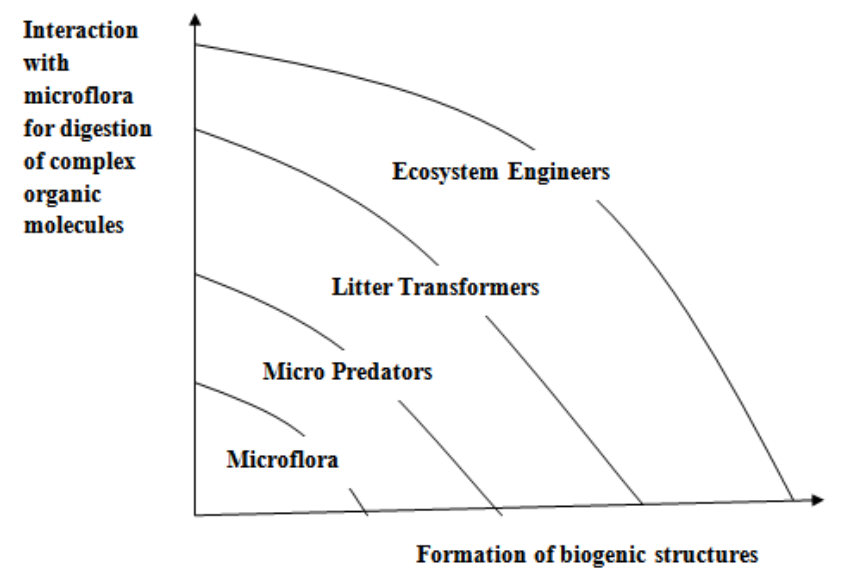

Figure 1. Soil Ecosystem engineers relation with other soil biological components. (Modified from Lavelle, 1997)

There is high degree of relationship exist between the microorganisms (fungi, actinomycetes, bacteria), micro-, meso-, and macro invertebrates (Protozoa, mites, springtails, millipedes, isopods, nematodes) with the anecic species of earthworm (Brown, 1995; Anderson and Bohlen, 1998; Maraun et. al. 1999) which are the chief biological creatures of drilosphere which involve in breaking down of complex organic molecules to form several biogenic structures. However, endogeic species have more influence with the microbial community rather than anecic species (Bhatnagar, 1975) because anecic species built permanent burrow system in soil (about $2 \mathrm{~m}$ depth) which is an important route of root growth activity and microbial dispersal (Ehlers et. al. 1983). Earthworm activity (preferentially endogeic species) is more around the rhizospheric region of plant roots $(0.5 \mathrm{~mm}$ thin soil layer attached to plant root surface) which are rich in microorganisms (James and Seastedt, 1986; Rovira et. al., 1987; Robertson et. al. 1994; Hirth et. al. 1998).

\subsection{Earthworm and Pedogenesis}

Soil formation i.e. Pedogenesis is not only the physicochemical process, it also involves the several biological phenomenon. Earthworm as macro fauna inhabitant of soil plays an important role in Pedogenesis. Earthworm helps to form the soil structure (Figure 2) by mineralizing and humifying the plant debris and organic residues. On the basis of morphology, habitat, and earthworm types; earthworms involve in the pedologic processes (Lavelle, 1988). The cast of the earthworm, fortified with mucilaginous secretion, helps in aggregate formation and stability (Shipitalo and Protz, 1988; Marinissen and Dexter, 1990) which is the foundation for soil structure formation. Water stable biogenic structures i.e. organomineral aggregates are found in the earthworm presence soil (Jouquet et. al. 2004; Bossuyt et. al., 2005; Jouquet et. al., 2009).

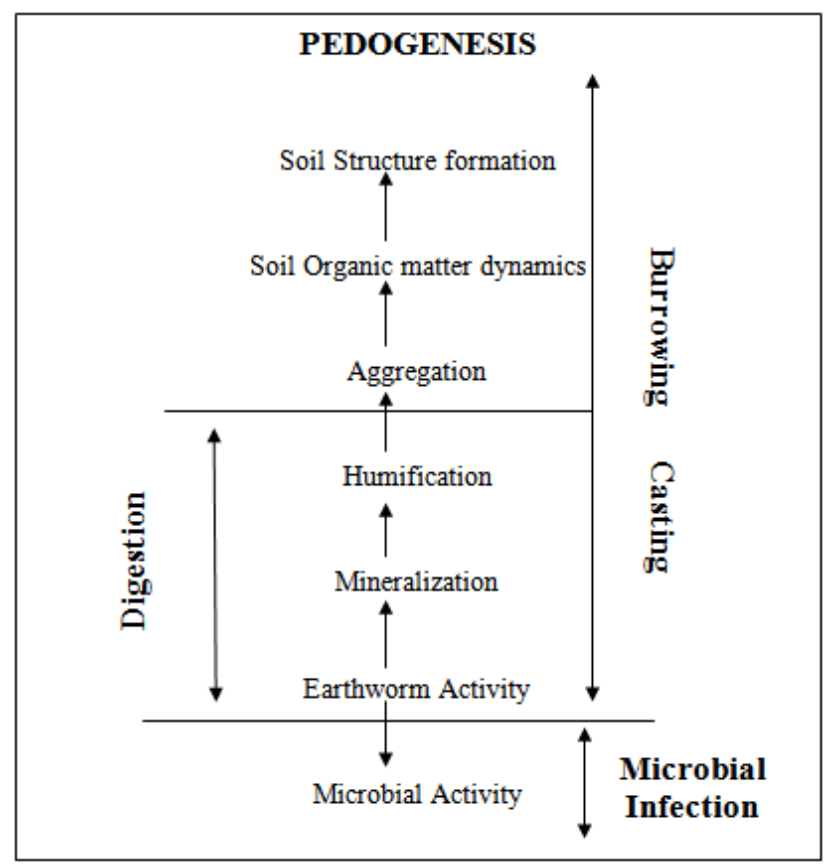

Figure 2. Earthworms role in Pedogenesis acting at various scale (modified from Lavelle et. al., 2004)

Earthworm have positive role in soil structure formation (Mackay and Kladivko, 1985; Ketterings et. al., 1997). Earthworms help to enhance the soil penetrability and reduce the soil compaction (Scott Russell, 1977) and enhance root distribution (Stockdill and Cossens, 1966; Ellis et al., 1977; Edwards and Lofty, 1978). Earthworms are also called 'natural tillers' because they increase aeration porosity (Knight et. al., 1992), infiltration capacity (Stockdill, 1966) and hydraulic conductivity (Ehlers, 1975; Johnson-Maynard et. al., 2002), water stable aggregates (Zeigler and Zech, 1992; Ketterlings et. al., 1992) of soil, decrease bulk density (Johnson-Maynard et.al., 2007). Whatever the types of earthworm, their role of bioturbation is significant and, hence, in Pedogenesis

\subsection{Earthworm and Organic Matter \& Nutrient Cycling}

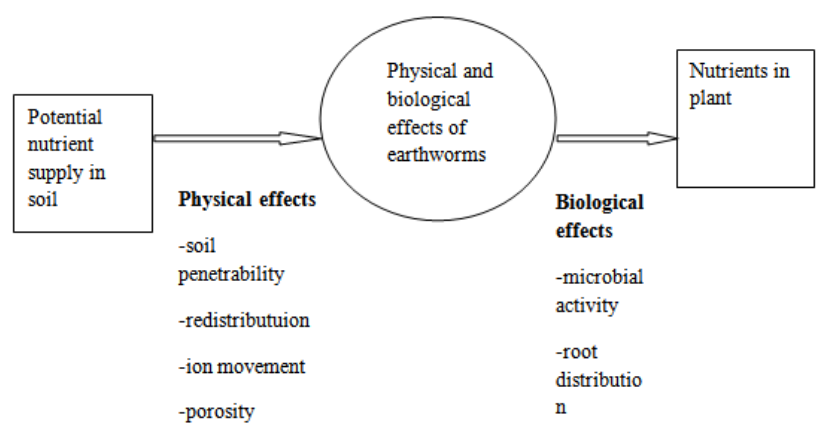

Figure 3. Influence of earthworm on soil physical and biological properties enhancing the nutrient supply in the soil. (Modified from Syers and Springett, 1984)

Earthworms enhance the fertility of soil by enhancing the soil physical, chemical and biological properties of soil. The role of earthworm in maintaining the soil fertility has been long discussed from Darwin (1881) up to this 
date. Several review papers and articles regarding beneficial effects of earthworm (Edwards and Lofty, 1982; Lee, 1985) have been published. A simple conceptual framework of the earthworm effects on soil properties to enhance soil nutrient cycling is presented in Figure 3.

Plant growth was affected by earthworm (Lal, 1999; Scheu, 2003) by enhancing the nutrient availability to the plants. The major feed source of earthworm in the soil is organic matter. So they play very a important role in organic matter cycling (Satchel, 1958). During the digestion process, soil mixes with the organic matter inside the gut of earthworms which then is incorporated into the soil profile. Loss of nitrate and ammonium nitrogen will be six to eight times less in the earthworm incorporated system (Sharpley et al., 1979).

Mobility of some nutrients such as phosphorous (less than $1 \mathrm{~mm}$ ) which is absorbed by the plants through root interception mechanism (Tisdale et al., 1985) is poor in the soil. Increasing root distribution and penetration more in the soil enhances the uptake of phosphorous as it provides more surface area for root interception. Root distribution and penetrability was increased by earthworm activity (Edwards and Lofty, 1978)

Earthworms near the rhizosphere of wheat plants were found to be abundant (Rovira et al., 1987) and similarly in maize (Binet et al., 1997) and in sugarcane (Spain et al., 1990). A functional interaction of earthworm with the microorganisms and plant growth is illustrated in Figure 4.

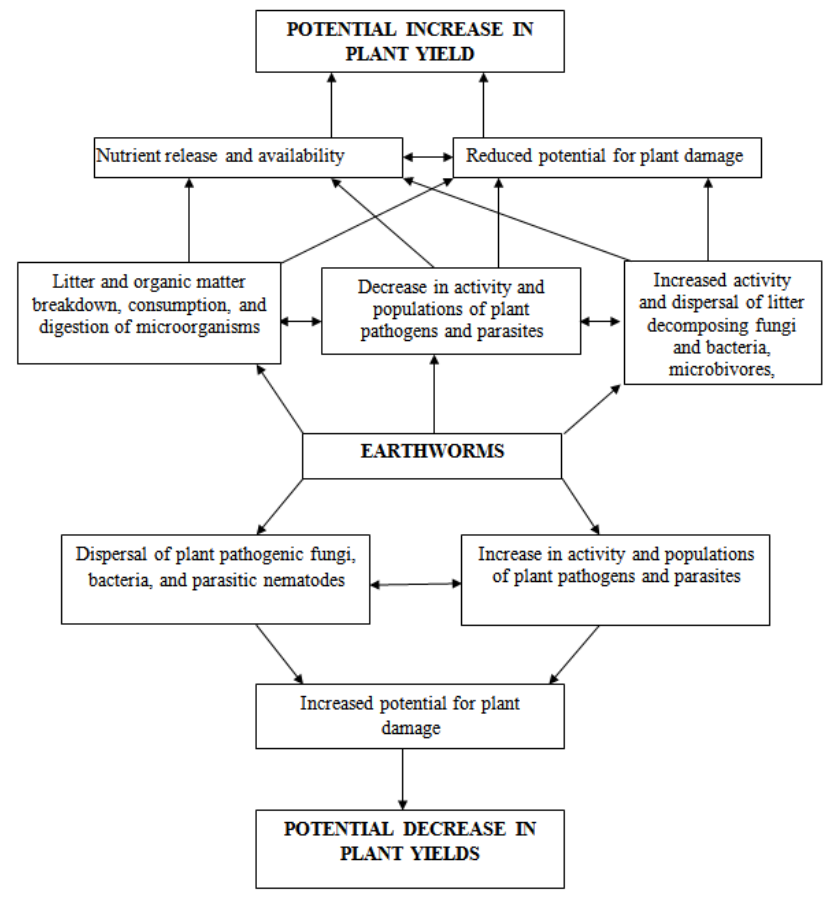

Figure 4. Beneficial and harmful microbes interact with earthworm and affect crop yield (modified from Edwards and Fletcher, 1988)

\section{Conclusion}

Presence of earthworm in different ecosystem differs with their types and habitat. There are lots of research papers found on the role of earthworm on soil properties. In a normal soil ecosystem their role was significant to bring changes in soil environment with their activity. But there is still some sort of gap present to find out earthworms performance in extreme environmental condition. There is certain contradiction found on the positive and negative role of earthworm in soil productivity. Very few paper talks about negative role of earthworm. Hence, further study is necessary to explore the role of earthworm in extreme conditions like, permanent water stagnation, puddled field condition. Still there is scope of earthworm study on the basis of temperature regime of soil.

\section{References}

[1] Agarwal, G., K. Rao and L. Negi. 1958. Influence of certain species of earthworms on the structure of some hill soils. Curr. Sci. 27: 213.

[2] Anderson OR and Bohlen PJ. 1998. Abundance and diversity of Gymnamoehae associated with earthworm (Lumbricus terrestris) middens in a northeastern U.S. forest. Soil Biol. Biochem., 30: 1213-1216.

[3] Barios, I., B. Verdier, P. Kaiser, A. Mariotti, P. Rangel and P. Lavelle. 1987. Influence if the tropical earthworm Pontoscolex corethrurus (Glossoscolecidae, Oligocheta) on the fixation and mineralization of nitrogen. In: P. Bonvicini and P. Omades (eds). On earthworms. Mucchi, Modens. Pp 151-158.

[4] Bhatnagar T. 1975. Lombriciens et Humification: un aspect nouveau de I'incorporation microbienne d'azote induite par les vers de terre. In Kilbertus, G., Reisinger, O., Mourey A., and da Fonseca, J.A.C. (Eds), Humification et Biodegradation, Pierron, Sarreguemines, France. Pp: 169-182.

[5] Binet, F., V. Hallaire, and P. Curmi. 1997. Agricultural practices and the spatial distribution of earthworms in maize fields. Relationships between earthworn abundance, maize plants and soil compaction. Soil Biol. Biochem. 29: 577-583.

[6] Bossuyt H, Six J, and Hendrix PF, 2005. Protection of soil carbon by microaggregates within earthworm casts. Soil Biol. Biochem. 37: 251-258.

[7] Bouché M.B. 1972. Lombriciens de France. Ecologie et systématique. Ann. Soc. Ecol. Anim. 72: 1671.

[8] Brown GG. 1995. How do earthworms affect microfloral and faunal community diversity? Plant Soil, 170: 209-231.

[9] Chan, K.Y., 2001. An overview of some tillage impacts on earthworm population abundance and diversity-implications for functioning in soils. Soil Tillage Res. 57: 179-191.

[10] Chutinan C, Jouqet P, Hanboonsong Y, Hartmann C. 2010. Effects of earthworms on soil properties and rice production in the rainfed paddy fields of Northeast Thailand. Applied soil Ecol. 45: 298-303

[11] Darwin, C. R. 1881. The formation of vegetable mould through the action of worms, with observations on their habits. Murray, London. p 326.

[12] Edwards C.A. and J.R. Lofty. 1978. The influence of arthropods and earthworms upon root growth of direct drilled cereals. J. of Appl. Ecol. 15: 789-795.

[13] Edwards, C. A. and J. R. Lofty. 1982. Nitrogenous fertilizer and earthworm population in agricultural soils. Soil Biol. Biochem. 14: 515-521.

[14] Edwards, C.A. 2004. The importance of earthworm as key representatives of soil fauna. In: C.A. Edwards (ed.) Earthworm Ecology. $2^{\text {nd }}$ edition. CRC press, NY, Washington, D.C. USA.

[15] Edwards, C.A. and K.E. Fletcher. 1988. Interactions between earthworms and microorganisms in organic matter breakdown. Agric. Ecosyst. Environ. 24: 235-247.

[16] Edwards, C.A., Lofty, J.R., 1982. The effect of direct drilling and minimal cultivation on earthworm populations. J. Appl. Ecol. 19: 723-734.

[17] Ehlers W, Kopke U, Hesse F, and Bohm W. 1983. Penetration resistance and root growth of oats in tilled and untilled loess soil. Soil Till and Res., 3: 261-275.

[18] Ehlers,W., 1975. Observations on earthworm channels and infiltration on tilled and untilled loess soil. Soil Sci. 119: 242-247.

[19] Ellis, F.B., J.G. Elliott, B.T. Barnes and K.R. Howse. 1977. Comparision of direct drilling, reduced cultivation and ploughing on the growth of cereals. 2. Spring barley on a sandy loam soil: soil physical conditions and root growth. J. Agric. Sci. 89: 631642. 
[20] Emmerling, C., 2001. Response of earthworm communities to different types of soil tillage. Appl. Soil Ecol. 17: 91-96.

[21] Gates GE. 1972. Burmese earthworms: an introduction to the systematics and biology of Megadrile oligochaetes with special reference to Southeast Asia. Trans. Amer. Phil. Soc. 62: 1-326.

[22] Hale, C.M., L.E. Frelich, P.B. Reich, and J. Pastor. 2005. Effects of European earthworm invasion on soil characteristics in northern hardwood forest of Minnesota USA. Ecosystem. 8: 911-927.

[23] Hirth JR, McKenzie BM, and Tisdall JM. 1998. Roots of perennial ryegrass (Lolium perenne) influence the burrowing of the endogeic earthworm, Apporrectodea rosea. Soil Biol. Biochem. 14: 2181-2183.

[24] James SW and Seastedt TR, 1986. Nitrogen mineralization by native and introduced earthworm effect on big bluestem growth. Ecology, 67: 1094-1097.

[25] Johnson-Maynard J.L., Umiker K.J., and S.O.Guy. 2007. Earthworm dynamics and soil physical properties in the first three years of no-till management. Soil Till. Res. 94: 338-345

[26] Johnson-Maynard, J.L., Graham, R.C., Wu, L., Shouse, P.J., 2002. Modification of soil structural and hydraulic properties after 50 years of imposed chaparral and pine vegetation. Geoderma 110: 227-240.

[27] Jouquet P, Bottinelli N, Podwojewski P, Hallaire V, Duc TT. 2008. Chemical andphysical properties of earthworm casts as compared to bulk soil under a range of different land-use systems in Vietnam. Geoderma 146, 231-238.

[28] Jouquet P, Zangerle A, Rumpel C, Brunet D, Bottinelli N, Tran Duc T. 2009. Relevance and limitations of biogenic and physicogenic classification: a comparison of approaches for differentiating the origin of soil aggregates. Eur. J. Soil Sci. 60: 1117-1125.

[29] Ketterings QM, Blair JM, Marinissen JCY. 1997. Effects of earthworm on soil aggregate stability and carbon and nitrogen storage in a legume cover crop agroecosystem. Soil Biol. Biochem. 29: 401-408.

[30] Kladivko, E.J., 2001. Tillage systems and soil ecology. Soil Tillage Res. 61, 61-76.

[31] Knight, D., Elliott, P.W., Anderson, J.M., Scholefield, D., 1992. The role of earthworms in managed, permanent pastures in Devon. Engl. Soil Biol. Biochem. 24: 1511-1517.

[32] Lal, R. 1999. Soil conservation and biodiversity. In: D.L. Hawksworth (ed). The Biodiversity of Microorganisms and Invertebrates: Its role in Sustainable Agriculture. CAB International, Wallingford, UK.

[33] Lavelle P. 1988. Earthworm activities and the soil system. Biol. Fertil. Soils 6: 237-251.

[34] Lavelle P. 1997. Faunal activities and soil processes: adaptive strategies that determine ecosystem function. Adv. Ecol. Res., 27: 93-132.

[35] Lavelle P., F. Charpentier, C. Villenave, J.P. Rossi, L, Derouard, B. Pashanasi, J. Andre, J.F. Ponge, and N. Bernier. 2004. Effect of Earthworms on Soil Organic Matter and Nutrient Dynamics at a Landscape over Decades. In: C.A. Edwards (ed.) Earthworm Ecology. $2^{\text {nd }}$ edition. CRC press, NY, Washington, D.C. USA. p. 147.

[36] Lavelle, P., D. Bigmell, M. Lepage, V. Wolters, P. Roger, P. Ineson, O.W. Heal, and S. Dhillion. 1997. Soil function in a changing world: the role of invertebrate ecosystem engineers. Eur. J. Soil Biol. 33: 159-193.

[37] Lee, K.E. 1985. Earthworms. Their Ecology and Relationships with Soils and Land Use. Academic press, Sydney, Australia.

[38] Lee, K.E., 1985. Earthworms their Ecology and Relationships with Soils and Land Use. Academic Press, Sydney. Lee, 1985.
[39] Mackay, A.D., Kladivko, E.J., 1985. Earthworm and rate of breakdown of soybean and maize residues in soil. Soil Biol. Biochem. 17, 851-857. Mackay and Kladivko, 1985.

[40] Maraun M, Alphei J, Bonkowski M, Buryn R, Migge S, Peter M, Schaefer M, and Scheu S. 1999. Middens of the earthworm Lumbricus terrestrisI (Lumbricidae): microhabitants for micro, and meso-fauna in forest soil. Pedobiologial, 43: 276-287.

[41] Marinissen, J.C.Y., Dexter, A.R., 1990. Machanisms of stabilization of earthworm casts and artificial casts. Biol. Fertil. Soils 9: 163-167.

[42] Robertson LN, Raford BJ, Bridge B, McGarry D, Blakemore RJ, and Sabag M. 1994. Tropical earthworms under cropping in Queensland. In Pankhurst CE (Ed)., Soil Biota: Management in sustainable farming system, CSIRO, East Melbourne, Australia. Pp: 33-34.

[43] Rose, C.J. and A.W. Wood. 1980. Some environmental factors affecting earthworm populations and sweet potato production in Tari basin, Papua New Guniea Highlands. Papua New Guinea Agric. J. 31: 1-13.

[44] Rovira AD, Smettem KRJ and Lee KE. 1987. Effect of rotation and conservation tillage on earthworms in red-brown earth under wheat. Aust. J. Agric. Res. 38: 829-834.

[45] Satchell, J.E. 1958. Earthworm biology and soil fertility. Soils and Fertilizers. 21: 209-219.

[46] Scheu, S. 2003. Effects of earthworms on plant growth: patterns and perspectives. Pedobiologia. 47 (5-6): 846-856.

[47] Schütz, K., Nagel, P., Dill, A., Scheu, S., 2008. Structure and functioning of earthworm communities in woodland flooding systems used for drinking water production. Appl. Soil Ecol. 9: 342-351.

[48] Scott Russell, R. 1977. Plant Root System: Their function and Interaction with the soil. Mc Graw-Hill Book Co., London. P 298.

[49] Sharpley A.N., J.K. Syers and J.A. Springett. 1979. Effects of surface-casting earthworns on the transport of phosphorous and nitrogen in surface runoff from pasture. Soil Biol. Biochem. 9: 227-231.

[50] Shipitalo, M.J., Protz, R., 1988. Factors influencing the dispersability of clay in worm casts. Soil Sci. Soc. Am. J. 52: 764769.

[51] Spain, A.V., P.G. Saffigna and A.D. Wood. 1990. Tissue carbon sources for Pontoscolex corethururs (Oligochaeta: glossoscolecidae) in a sugarcane ecosystem. Soil Biol. Biochem. 22: 703-706.

[52] Stockdill, S.M.J. and G.G. Cossens. 1966. The role of earthworms in pasture production and moisture conservation. Proc. N.Z. Grassland Assoc. 28: 168-183.

[53] Stockdill, S.M.J., 1966. The effect of earthworms on pastures. Proc. N. Z. Ecol. Soc. 13: 68-75.

[54] Syers, J. K. and J. A. Springett. 1984. Earthworms and soil fertility. Plant Soil. 76: 93-104.

[55] Tisdale, S. L., W. L. Nelson and J. D. Beaton. 1985. Soil Fertility and Fertilizers. The Macmillian Company. New York. Pp: 754.

[56] Wardle, D.A., 1995. Impacts of disturbance on detritus food webs in agro-ecosystems of contrasting tillage and weed management practices. Adv. Ecol. Res. 26: 105-185.

[57] Ziegler, F., Zech, W., 1992. Formation of water-stable aggregates through the action of earthworms: Implications from laboratory experiments. Pedobiologia 36: 91-96.

[58] Zorn, M.I., Van Gestel, C.A.M., Morrien, E., Wagenaar, M. Eijsackers, H., 2008. Flooding responses of three earthworm species, Allolobophora chlorotica, Aporrectodea caliginosa and Lumbricus rubellus, in a laboratory-controlled environment. Soil Biol. Biochem. 40: 587-593. 